\title{
Cultured Endothelial Cells Synthesize Both Platelet-activating Factor and Prostacyclin in Response to Histamine, Bradykinin, and Adenosine Triphosphate
}

\author{
Thomas M. Mclntyre, Guy A. Zimmerman, Kei Satoh, and Stephen M. Prescott \\ Nora Eccles Harrison Cardiovascular Research and Training Institute, and Department of Internal Medicine, \\ University of Utah School of Medicine, Salt Lake City, Utah 84112
}

\begin{abstract}
Cultured human endothelial cells synthesize prostacyclin $\left(\mathbf{P G I} \mathbf{I}_{\mathbf{2}}\right.$, a potent inhibitor of platelet function, when stimulated with histamine, bradykinin, or ATP. Paradoxically, we report that these agonists also induced the rapid and sustained synthesis of platelet-activating factor (PAF) by endothelial cells. In fact, the synthesis of this potent activator of platelets and neutrophils was induced by stimulation of the same receptor subtype that induced $\mathrm{PGI}_{2}$ synthesis: stimulation of a histamine $\mathrm{H}_{1}$ or a bradykinin $\mathrm{B}_{2}$ receptor induced both PAF and PGI 2 synthesis. However, two physiologically important differences exist between the production of PAF and PGI 2 by endothelial cells. The synthesis of PGI $_{2}$ proceeded for only $7.5 \mathrm{~min}$ before the abrupt termination of synthesis, whereas the synthesis of PAF was clearly detectable even $45 \mathrm{~min}$ after stimulation. Although maximal accumulation of PAF occurred after 10-15 $\mathrm{min}$ of stimulation, the prolonged synthesis resulted in the presence of PAF for up to $1 \mathrm{~h}$ after stimulation. Secondly, whereas PGI was released from the cell monolayer, PAF remained cellassociated without significant release to the external medium. Endothelial cell-generated PAF, therefore, does not function as a hormone. The prolonged association of this potent activator of platelets and neutrophils with endothelial cells may mediate some of the inflammatory properties of histamine and bradykinin. It may also be a factor in the formation of a thrombogenic vascular surface, an event suggested to play a primary role in the pathogenesis of thrombosis and atherosclerosis.
\end{abstract}

\section{Introduction}

Vascular endothelium is composed of a single layer of endothelial cells that mediates the interaction of the blood with the rest of the organism. Among the functions demonstrated by endothelial cells is the presentation of a surface that does not activate the hemostatic system and thereby induce the formation of thrombi. This property is not shared by either the substratum or the smooth muscle cells and fibroblasts that underlie the

A preliminary report of portions of this work has been presented to the 57th Scientific Session of the American Heart Association at Miami Beach, FL, on 12 November 1984, and has been published as an abstract (1984. Circulation. 70[Suppl.]:A211).

Address reprint requests to Dr. McIntyre, Nora Eccles Harrison CVRTI, Bldg. 100, University of Utah, Salt Lake City, UT 84112.

Received for publication 10 August 1984 and in revised form 19 March 1985.

J. Clin. Invest.

(C) The American Society for Clinical Investigation, Inc

0021-9738/85/07/0271/10 \$1.00

Volume 76, July 1985, 271-280 endothelium. The difference in the endothelial cell surface that results in thromboresistance is not defined, but it is known that endothelium (1) and cultured endothelial cells (2) synthesize prostacyclin $\left(\mathrm{PGI}_{2}\right)^{1}$ in response to a number of physiologic stimuli (3-7). Initially, the synthesis of this potent inhibitor of platelet aggregation and activation was postulated to participate in the maintenance of a nonthrombogenic surface (1). However, it is now apparent that endothelial cells secrete little, if any, $\mathrm{PGI}_{2}$ in the absence of appropriate agonists, and inhibition of the cyclooxygenase activity with aspirin does not alter the adhesion of platelets to unstimulated endothelium (8). The role of $\mathrm{PGI}_{2}$ is further obscured by the observation that stimulation of the endothelium with thrombin, a potent agonist for $\mathrm{PGI}_{2}$ secretion, actually results in the loss of thromboresistance $(8,9)$.

The recent observation $(10,11)$ that endothelial cells make platelet-activating factor (PAF) in response to physiologic concentrations of thrombin may explain the generation of a thrombogenic surface in response to this agent. PAF, identified as 1-alkyl-2-acetyl-sn-glycero-3-phosphocholine (12), has the unusual property of being a potent agonist for the activation of both platelets and granulocytes (13), and treatment of endothelial cells with thrombin has been shown to increase the adhesion of granulocytes (10) and platelets (8) to the cell monolayer.

The synthesis of both PAF and $\mathrm{PGI}_{2}$ in response to thrombin was unanticipated due to the potent, but opposing actions of these two agents on platelet and neutrophil function. Inasmuch as the nature of the endothelial cell recognition system for thrombin has not yet been explicitly defined, it is possible that thrombin induces two separate signals, and that the co-stimulation of PAF and $\mathrm{PGI}_{2}$ synthesis is coincidental. In order to understand better the relationship between the synthesis of PAF and $\mathrm{PGI}_{2}$, agonists that prompt endothelial cells to synthesize $\mathrm{PGI}_{2}$ by a receptor-mediated mechanism were examined for their potential to also induce the synthesis of PAF. We found that agonists that promoted endothelial cell synthesis of $\mathrm{PGI}_{2}$, namely, histamine (4), bradykinin (5), and ATP (7), induced the synthesis of PAF as well. The inflammatory mediators histamine and bradykinin have well characterized receptors, which has allowed us to demonstrate that the stimulation of a single receptor subtype, a histamine $\mathrm{H}_{1}$ or a bradykinin $B_{2}$ receptor, resulted in the simultaneous induction of PAF and $\mathrm{PGI}_{2}$ synthesis. Although the induction of synthesis of PAF and $\mathrm{PGI}_{2}$ was tightly correlated, the synthesis and accumulation of PAF by endothelial cells extended well beyond

1. Abbreviations used in this paper: EDRF, endothelium-derived relaxing factor; HPLC, high-pressure liquid chromatography; PAF, platelet-activating factor, 6-keto-PGF ${ }_{1 \alpha}, 6$-keto-prostaglandin $\mathrm{F}_{1 \alpha} ; \mathrm{PGI}_{2}$, prostacyclin; TLC, thin-layer chromatography. 
the abrupt end of $\mathrm{PGI}_{2}$ synthesis. The endothelial cell-generated PAF was not released from the cells and remained associated with the cells even in the presence of physiological albumin concentrations. Because this PAF would not circulate in vivo, it is not likely to function as a hormone. Endothelial cellassociated PAF, however, may mediate some of the interactions of the endothelium with blood-borne cells. Such interactions may account for some of the effects of two of the classic mediators of inflammation, histamine and bradykinin, and also may play a role in vascular thrombogenesis.

\section{Methods}

1-O-[1',2'-3 H]Alkyl-2-acetyl-sn-glycero-3-phosphocholine $(45 \mathrm{Ci} / \mathrm{mmol})$, sodium $\left[{ }^{3} \mathrm{H}\right]$ acetate $(2.8 \mathrm{Ci} / \mathrm{mmol})$, and $6-\left[5,8,9,11,12,14,15-{ }^{3} \mathrm{H}(N)\right]$ ketoprostaglandin $\mathrm{F}_{1 \alpha}$ (6-keto-PGF $\mathrm{F}_{1 \alpha}$ ) were purchased from New England Nuclear (Boston, MA). Platelet-activating factor (1-O-alkyl-2-acetyl-snglycero-3-phosphocholine, PAF), bovine serum albumin (essentially fatty acid-free), histamine, pyrilamine, cimetidine, bradykinin and its analogues were from Sigma Chemical Co. (St. Louis, MO). Sigma Chemical Co. also supplied adenosine, AMP, ADP, ATP, 2'-deoxyATP, inosine, inosine monophosphate, inosine diphosphate, and inosine triphosphate. The methylene and imido substituted analogues of ATP were from Pharmacia Fine Chemicals/P-L Biochemicals Inc. (Piscataway, NJ). Histamine analogs were the kind gift of Dr. Nancy L. Baenziger (Washington University, St. Louis), and purified human thrombin was generously provided by Dr. George J. Broze (Washington University, St. Louis).

Human endothelial cells were harvested from umbilical veins and grown to confluence in gelatin-coated 35-mm tissue culture dishes as previously described (10). Agonist-stimulated PAF accumulation was determined by using a slight modification of our previous protocol (10). The assay was initiated by replacing the growth medium with 1 ml of Hanks' buffered saline-10 mM $N$-2-hydroxyethyl-piperazine- $N^{\prime}$ 2-ethanesulfonic acid (Hepes), $\mathrm{pH} \mathrm{7.4,} \mathrm{containing} 25 \mu \mathrm{Ci}$ of carrierfree $\left[{ }^{3} \mathrm{H}\right]$ acetate. After incubation at room temperature for the stated time, the assay was terminated by the addition of $0.5 \mathrm{ml}$ of $50 \mathrm{mM}$ acetic acid in methanol. Labeling at this temperature resulted in only marginally less radioactivity incorporated into PAF than when the cells were labeled at $37^{\circ}$ (13a). The cells remained viable and responsive in this serum-free buffer for $15 \mathrm{~h}$, a period of time much longer than any incubation used in this study.

The material from all terminated assays was collected as follows: cells in acidified medium were scraped from the plate; the plate was washed twice with $1 \mathrm{ml}$ of methanol; $7 \mathrm{nmol}$ carrier PAF were added; and $1.25 \mathrm{ml}$ of chloroform was added to the pooled fluid to form a monophase (14). The monophase was split with $\mathrm{CHCl}_{3}$ and $0.1 \mathrm{M}$ $\mathrm{NaAc}$, and the lower phase was washed three times with preequilibrated upper phase. This was dried under $\mathrm{N}_{2}$ and the lipids were resuspended in $\mathrm{CHCl}_{3} / \mathrm{MeOH}$ (9:1). An aliquot of the recovered lipids was used to determine the total amount of radioactivity present, while the remainder was fractionated by thin-layer chromatography (TLC) that used silica gel 60 (Merck \& Co., Darmstadt, Federal Republic of Germany) and solvent system II of Mueller et al. (15). Areas containing PAF, identified by $\mathrm{H}_{2} \mathrm{O}$ misting, and the remainder of the lane were separately scraped into scintillation vials for quantitation. Duplicate assays show that the mean variation of PAF production by cultures derived from the same vein was $\pm 5 \%$. Chromatography in a second TLC system (16) showed that $\left[{ }^{3} \mathrm{H}\right]$ acetate-labeled lipids elicited by histamine, bradykinin, or ATP migrated with authentic 1-alkyl-2acetyl-sn-glycero-3-phosphocholine. Treatment of each of these radiolabeled lipids with Crotalus adamanteus phospholipase $A_{2}(10)$ showed that at least $90 \%$ of the radioactivity was incorporated into the $s n-2$ position. Treatment with Rhizopus arrhizus phospholipase $\mathrm{A}_{1}$ showed that $<10 \%$ of the radioactive PAF contained an $s n-1$ fatty acyl residue.

The partitioning of the newly synthesized PAF between the cell monolayer and the overlying fluid was examined using assay buffer or assay buffer supplemented with bovine serum albumin (essentially fatty acid-free). In these experiments, the assay was terminated by removing the assay medium and adding $50 \mathrm{mM}$ acetic acid in $1.5 \mathrm{ml}$ methanol/water $(0.5: 1)$ to the cell monolayer. The fluid removed from the plate was acidified with methanolic acetic acid and, excepting that the Bligh-Dyer monophase was centrifuged to remove precipitated albumin, these fractions were processed as before. Six separate experiments have shown that only a small percentage of the PAF is released from endothelial cells, with or without the addition of albumin to the assay buffer.

The rate of synthesis of PAF during agonist stimulation was estimated in two separate experiments by quantitating the amount of $\left[{ }^{3} \mathrm{H}\right] \mathrm{PAF}$ generated during a 3-min pulse of $\left[{ }^{3} \mathrm{H}\right]$ acetate. The endothelial cell growth medium was exchanged for buffer containing an agonist, but no $\left[{ }^{3} \mathrm{H}\right]$ acetate. At the specified time, this buffer was exchanged for 1 $\mathrm{ml}$ of buffer supplemented with $50 \mu \mathrm{Ci}$ of $\left[{ }^{3} \mathrm{H}\right]$ acetate in addition to the agonist. The labeling was allowed to proceed for $3 \mathrm{~min}$ before the assay was terminated and processed as described above. The 3-min pulse protocol should reflect the rate of PAF synthesis as the degradation of exogenously added PAF was slow. The rate of hydrolysis of $1 \mathrm{nmol}$ (in $1 \mathrm{ml}$ ) of $\left[{ }^{3} \mathrm{H}\right.$-alkyl]PAF by endothelial cells was measured at 2-min intervals over a $10-$ min period and the accumulation of $1-\left[{ }^{3} \mathrm{H}\right]$ alkyl$s n$-glycero-3-phosphocholine was linear with time and equal to $0.0028 \mathrm{nmol} / \mathrm{min}$ per $\left(8 \times 10^{5}\right.$ cells $=$ one dish $)$. Even with this amount of PAF, which was 5-10-fold higher than the maximal amount accumulated by $8 \times 10^{5}$ endothelial cells, the hydrolytic rate was $10 \%$ of the maximal rate of accumulation (10). The rate of PAF hydrolysis was not altered by agonist stimulation of the cells. The pulse-labeling protocol was also verified by pulse-labeling endothelial cells for various 3-min intervals over the first 12 min of stimulation and comparing the sum of this pulse-labeled PAF to the amount of PAF generated in the same experiment when measured by continuous $\left[{ }^{3} \mathrm{H}\right]$ acetate labeling. The sum of the $\left[{ }^{3} \mathrm{H}\right] \mathrm{PAF}$ generated by the pulse-labeled plates was within $10 \%$ of the amount of $\left[{ }^{3} \mathrm{H}\right] \mathrm{PAF}$ accumulated by the continuously labeled endothelial cells, so pulse labeling accurately reflects the process which results in the accumulation of $\left[{ }^{3} \mathrm{H}\right]$ acetate-labeled PAF.

The amount of PAF bioactivity present in high-pressure liquid chromatography (HPLC) fractions derived from two pooled agoniststimulated or control monolayers was determined by monitoring the aggregation of isolated human polymorphonuclear leukocytes as described (10). These samples did not have carrier PAF added to the extraction step. The HPLC system employed a Varian $4.6 \times 300-\mathrm{mm}$ Micropak Si-5 column (Varian Associates, Inc., Palo Alto, CA) and the solvent system of Blank and Snyder (17).

The production of prostacyclin was determined by quantitation of the stable breakdown product, 6-keto-PGF ${ }_{1 \alpha}$, by a radioimmunoassay that used antibody generously provided again by Dr. Nancy Baenziger (Washington University, St. Louis, MO). Confluent cell monolayers were overlaid with $1 \mathrm{ml}$ of buffer with or without agonist, and at the indicated times $100-\mu \mathrm{l}$ aliquots were removed for 6-keto-PGF ${ }_{1 \alpha}$ quantitation. The volume of the assay was maintained by the addition of an equal volume of appropriate buffer, and the data presented have been corrected for the resulting dilution.

The effect of PAF on the tension of isolated canine femoral arterial rings was determined (18) by using a Grass Instrument Co. (Quincy, MA) FT-03 force transducer. The mounted ring was continuously perfused with Tyrodes solution equilibrated at $37^{\circ} \mathrm{C}$ with $\mathrm{O}_{2} / \mathrm{CO}_{2}(95$ : 5 ) while the resting tension was stabilized at $2 \mathrm{~g}$. Agents were tested by stopping this flow, adding the agent to the $10-\mathrm{ml}$ organ bath that was continuously bubbled with the $\mathrm{O}_{2} / \mathrm{CO}_{2}$ mixture, and recording the strain gauge output with a strip-chart recorder. The effector compounds were removed by reinitiating buffer flow.

\section{Results}

Human endothelial cells make PAF in response to histamine. When human endothelial cells were stimulated with histamine, 
they rapidly incorporated $\left[{ }^{3} \mathrm{H}\right]$ acetate into a polar lipid that co-migrated in a HPLC system with authentic PAF. A standard of semisynthetic 1-alkyl-2-acetyl-sn-glycero-3-phosphocholine (PAF) eluted as a peak centered at 32-33 min (Fig. $1 \mathrm{~A}$ ). The $\left[{ }^{3} \mathrm{H}\right]$ acetate-labeled polar lipid from histamine-stimulated cells eluted as a peak $32 \mathrm{~min}$ after injection onto the column (Fig. $1 \mathrm{~B}$ ). This material was not present in cells incubated in the absence of histamine, and was the only change in acetatelabeling after histamine stimulation. The lipid from histaminestimulated cells that eluted from the HPLC column at $30 \mathrm{~min}$ possessed biologic activity characteristic of PAF. This material was able to induce the aggregation of cytochalasin B-treated human polymorphonuclear leukocytes (Fig. $1 C$ ). Bioactive material was not present in the corresponding fractions from unstimulated endothelial cells.

The amount of PAF synthesized by endothelial cells was dependent upon the concentration of histamine employed as a stimulus (Fig. $2 \mathrm{~A}$ ). A response was detectable at $10^{-7} \mathrm{M}$ histamine and, in this experiment, was maximal at $\sim 5 \times 10^{-5}$ M. Although the response of cells isolated from a single umbilical vein was quite uniform, the concentration of histamine required for maximal stimulation varied up to fivefold among the cell isolates from different veins.

The addition of histamine to the cultured cells resulted in the immediate induction of cellular PAF synthesis (Fig. $2 \mathrm{~B}$ ). Accumulation of PAF by endothelial cells increased with time during the first $10 \mathrm{~min}$ of histamine stimulation. Half of this accumulated PAF was then lost in the succeeding $5 \mathrm{~min}$ of incubation, followed by a slower rate of loss over the next 45 min. This pattern resulted in measurable amounts of cellassociated PAF for up to $1 \mathrm{~h}$ after the initiation of histamine stimulation.

The duration of the accumulation of PAF by endothelial cells in response to histamine was markedly different from the time course of histamine-elicited $\mathrm{PGI}_{2}$ release from endothelial cells. The quantitation of 6-keto-PGF ${ }_{1 \alpha}$, the stable degradation product of $\mathrm{PGI}_{2}$, by radioimmunoassay showed that unstimulated monolayers released little $\mathrm{PGI}_{2}$ to the medium (Fig. 3). Histamine stimulation induced the linear accumulation of 6keto-PGF ${ }_{1 \alpha}$ in the medium for $7.5 \mathrm{~min}$ before the abrupt termination of this accumulation. This pattern of 6-ketoPGF $_{1 \alpha}$ accumulation was identical (Fig. 3) to that produced by thrombin, another agonist for PAF synthesis (10). The cessation of 6-keto-PGF $\mathrm{P}_{\alpha}$ accumulation at $7.5 \mathrm{~min}$ shows that $\mathrm{PGI}_{2}$ synthesis was terminated or sharply reduced by this time. Thus, whereas endothelial cells synthesize both PAF and $\mathrm{PGI}_{2}$ in response to histamine and thrombin (10), the presence of endothelial cell PAF persisted well beyond the burst of $\mathrm{PGI}_{2}$ synthesis and release from the cell monolayer.

Histamine stimulates both PAF and PGI, synthesis via an $H_{1}$ receptor. Stimulation of $\mathrm{PGI}_{2}$ synthesis by human endothelial cells in response to histamine has been shown to be mediated through an $\mathrm{H}_{1}$-type receptor (4). The data in Table I show that the histamine stimulation of PAF synthesis by endothelial cells is also mediated by an $\mathrm{H}_{1}$-type receptor. The classic $\mathrm{H}_{1}$ antagonist, pyrilamine, reduced the histamine response by $\sim 95 \%$; cimetidine, an $\mathrm{H}_{2}$ antagonist, reduced this response by only $2 \%$. In addition, PAF synthesis was induced by both of the $\mathrm{H}_{1}$ receptor-specific agonists (19) tested. The magnitude of this stimulation was equivalent to or slightly greater than the histamine response itself. $\mathrm{H}_{2}$-type agonists $(19,20)$ did not stimulate the synthesis of PAF by endothelial cells.
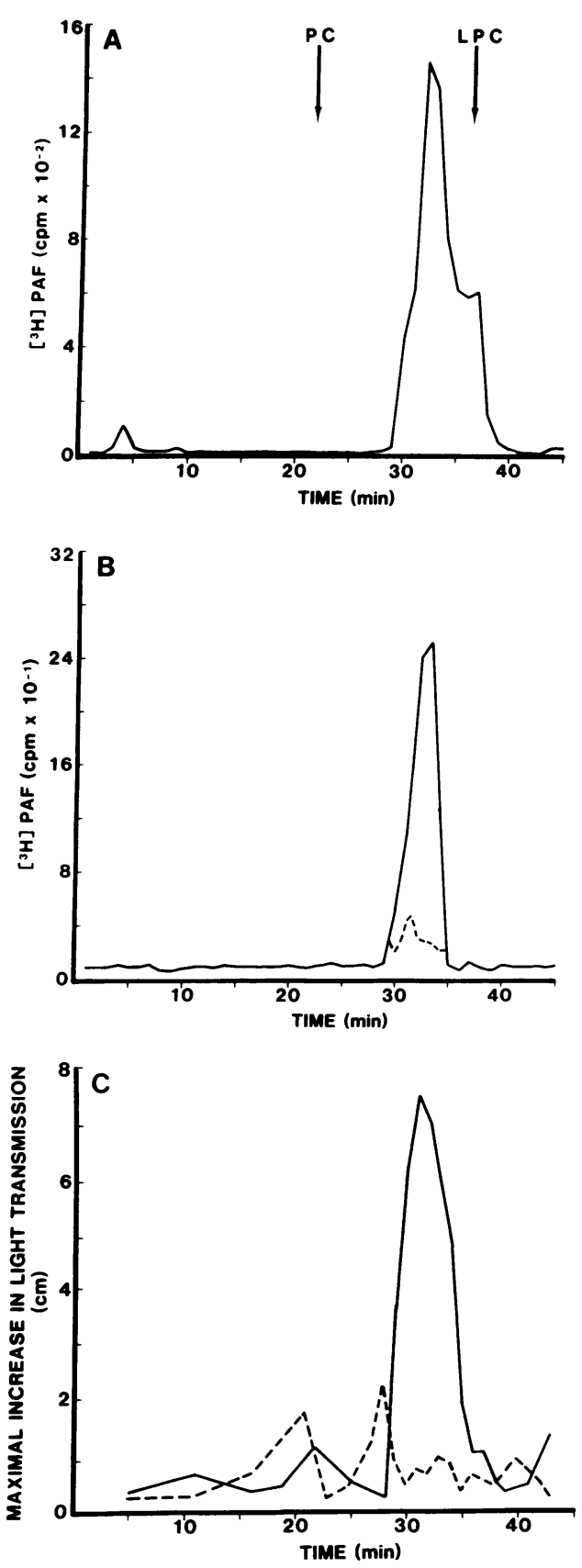

Figure 1. Histamine stimulates human endothelial cells to synthesize PAF. The medium overlaying confluent monolayers of human endothelial cells was exchanged for buffer with or without $10^{-5} \mathrm{M}$ histamine. After $5 \mathrm{~min}$ at $24^{\circ} \mathrm{C}$, the incubation was stopped with acidic methanol as described in Methods. The material to be tested for bioactivity was derived from two pooled culture plates and carrier PAF was not added to this extraction. Extracted lipids were injected onto a $4.6 \times 300-\mathrm{mm}$ Micropak Si-5 HPLC column and eluted at 1 $\mathrm{ml} / \mathrm{min}$ as described (17). Fractions were collected at 0.5 -min intervals and the radioactivity in the entire fraction was quantitated. Fractions from unlabeled cells were prepared for bioassay as described in Methods. This chromatogram is representative of the results obtained from three separate experiments. $(A) 1-\left[{ }^{3} \mathrm{H}\right]$ alkyl-2acetyl-sn-glycero-3-phosphocholine standard. The elution position of phosphatidylcholine $(P C)$ and 1-O-alkyl-sn-glycero-3-phosphocholine $(L P C)$ standards is shown by an arrow. $(B)\left[{ }^{3} \mathrm{H}\right]$ Acetate-labeled lipid from histamine-stimulated endothelial cells (-); and unstimulated cells (- - ). (C) Granulocyte aggregation activity from histaminestimulated endothelial cells $(-)$; and unstimulated cells (- - ). 

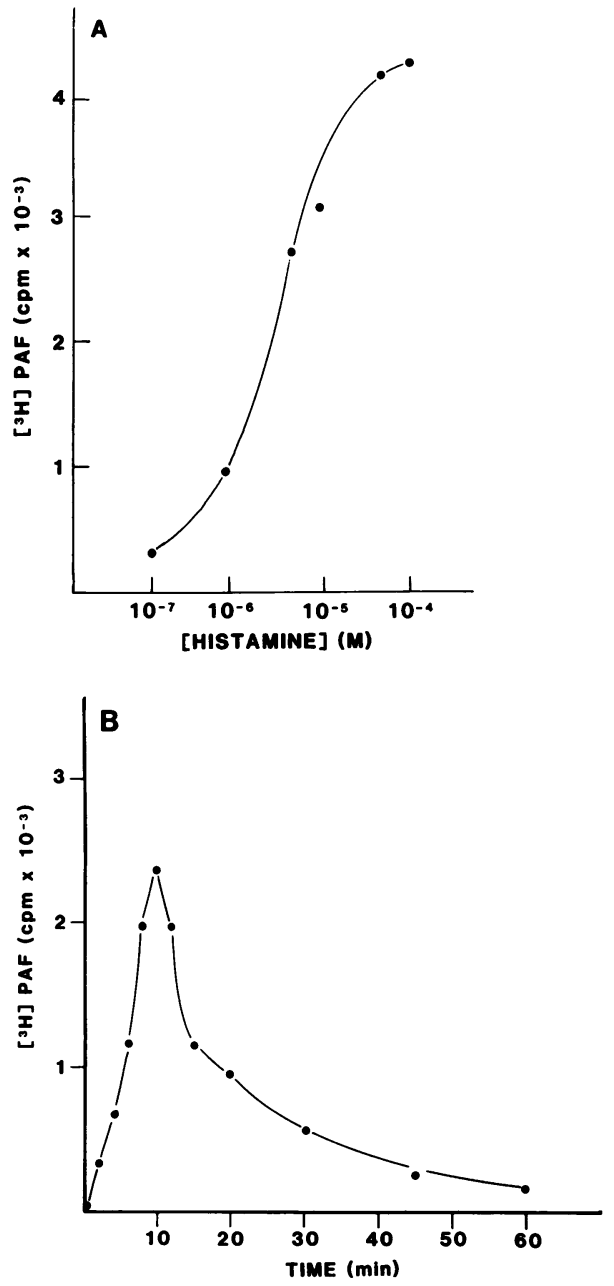

Figure 2. Accumulation of PAF by human endothelial cells as a function of histamine concentration or time. $(A)$ The concentration of histamine employed to stimulate confluent monolayers of endothelial cells was varied. Cells were stimulated for $10 \mathrm{~min}$ in medium containing $\left[{ }^{3} \mathrm{H}\right]$ acetate and the amount of radioactivity co-migrating with authentic PAF was determined as described in Methods. Five such experiments indicate that the response to histamine is concentration-dependent, but that the half-maximal concentration and the peak value can vary in different endothelial cell isolates. $(B)$ Accumulation of PAF after stimulation with $10^{-5} \mathrm{M}$ histamine for various periods of time was determined as described in Methods. These results are typical of four separate experiments.

Bradykinin stimulates endothelial cell PAF synthesis. Human endothelial cells, and those derived from other species, have been shown to respond to bradykinin by synthesizing $\mathrm{PGI}_{2}$ (5). To determine whether or not PAF synthesis would also be initiated in response to this $\mathbf{P G I}_{2}$ agonist, confluent monolayers of human endothelial cells were exposed to MetLys-bradykinin, a natural analogue of bradykinin that effectively stimulates both $B_{1}$ and $B_{2}$ receptors (21). The resulting data (Fig. 4) show that Met-Lys-bradykinin does indeed stimulate the synthesis of PAF in a time- and concentration-dependent manner. Synthesis and accumulation of PAF began immediately upon Met-Lys-bradykinin addition and the accumulation of PAF reached its maximum value 8-10 min later. The amount of PAF then gradually declined throughout the remainder of the experiment. This pattern resulted in the persistence of at

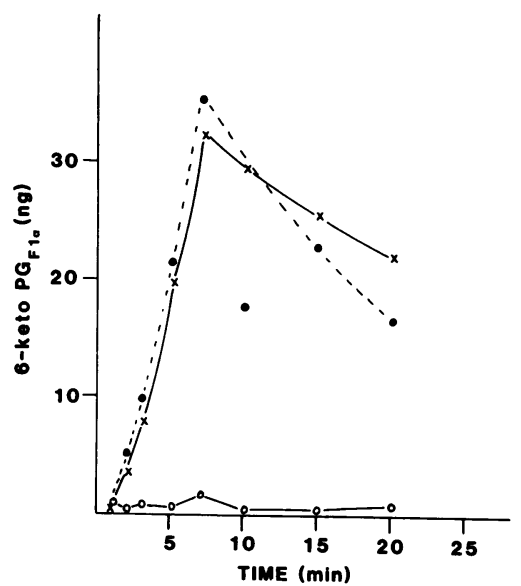

Figure 3. Effect of time of stimulation on $\mathrm{PGI}_{2}$ production. Accumulation of the 6-keto-PGF ${ }_{1 \alpha}$ breakdown product of $\mathbf{P G I}_{2}$ in the medium of histamine-stimulated or thrombin-stimulated cells. Aliquots of the assay medium were taken at the designated times and the amount of 6-keto-PGF I $_{1 \alpha}$ was determined by radioimmunoassay as described under Methods. The brief burst of 6-keto-PGF $F_{1 \alpha}$ release was confirmed in five additional experiments. The medium contained $10^{-5} \mathrm{M}$ histamine (๑); $2 \mathrm{U} / \mathrm{ml}$ human thrombin ( $\mathrm{x}$ ); or no additions $(0)$

least half of the cellular PAF even 30 min after the addition of Met-Lys-bradykinin to the cells. The inset shows that maximal stimulation was achieved with $\sim 10^{-6} \mathrm{M}$ Met-Lysbradykinin.

The presence of PAF at times well after Met-Lys-bradykinin stimulation of the cultured cells implied that the synthesis of PAF might be a protracted process. Therefore, the rate of synthesis of PAF was approximated by adding $\left[{ }^{3} \mathrm{H}\right]$ acetate for a 3-min labeling period at various times after stimulation in medium initially lacking labeled acetate. The rate of synthesis was found to be greatest during the initial $3 \mathrm{~min}$ of stimulation, and then decreased with time (Fig. 5). However, $20 \mathrm{~min}$ after Met-Lys-bradykinin addition, the rate of synthesis was still over one-third of the initial value, and even $45 \mathrm{~min}$ after stimulation, the rate of PAF synthesis was three times the background rate.

Stimulation of bradykinin $B_{2}$ receptors induces both $P A F$ and $\mathrm{PGI}_{2}$ synthesis. The stimulation of both $\mathrm{PAF}$ and $\mathrm{PGI}_{2}$ synthesis by activation of an $\mathrm{H}_{1}$ receptor raised the possibility that a single type of bradykinin receptor might also be responsible for the stimulation of both PAF and $\mathbf{P G I}_{2}$ synthesis. The data shown in Table II indicates that the induction of PAF and $\mathbf{P G I}_{2}$ synthesis results from the stimulation of a $\mathbf{B}_{2}$-type receptor: the order of potency (bradykinin $\geqq$ Lys-bradykinin $\geqq$ Met-Lys-bradykinin) was that expected of a $\mathbf{B}_{2}$-type receptor (21); the amount of PAF resulting from a 5-min stimulation with bradykinin or Met-Lys-bradykinin (a potent $B_{1}$ - and $B_{2^{-}}$ receptor agonist) was not affected by a selective (21) $B_{1}$ receptor antagonist (des-Arg9-[Leu $\left.{ }^{8}\right]$ bradykinin); and a selective $B_{1}$-receptor agonist (des-Arg'-bradykinin) did not stimulate PAF synthesis by endothelial cells.

Examination of $\mathrm{PGI}_{2}$ production in parallel with $\mathrm{PAF}$ determinations gave the same results: the order of potency was that expected for a $\mathbf{B}_{2}$ receptor; a $\mathbf{B}_{1}$-receptor antagonist was unable to inhibit stimulation; and a $B_{1}$-receptor agonist was an ineffective stimulus. These data indicate that $\mathbf{P G I}_{2}$ synthesis 
Table I. Histamine Stimulates Endothelial Cell PAF Synthesis via an $H_{1}$-type Receptor

\begin{tabular}{|c|c|c|c|c|c|c|c|}
\hline Agonist & $\begin{array}{l}\text { Receptor } \\
\text { type }\end{array}$ & Antagonist & $\begin{array}{l}\text { Receptor } \\
\text { type }\end{array}$ & PAF & Agonist & $\begin{array}{l}\text { Receptor } \\
\text { type }\end{array}$ & PAF \\
\hline & & & & $\%$ & & & $\%$ \\
\hline \multirow[t]{6}{*}{ Histamine } & $\mathbf{H}_{1}, \mathbf{H}_{2}$ & - & - & 100 & Histamine & $\mathbf{H}_{1}, \mathbf{H}_{2}$ & 100 \\
\hline & & Pyrilamine & $\mathrm{H}_{1}$ & 4.6 & 2-(2-Pyridyl)ethylamine & $\mathbf{H}_{1}$ & 131 \\
\hline & & Cimetidine & $\mathbf{H}_{2}$ & 98.6 & 2-Methylhistamine & $\mathrm{H}_{1}$ & 117 \\
\hline & & Pyrilamine & $\mathbf{H}_{\mathbf{l}}$ & & 4-Methylhistamine & $\mathbf{H}_{2}$ & 0 \\
\hline & & + & & 7.8 & Dimaprit & $\mathrm{H}_{2}$ & 0 \\
\hline & & Cimetidine & $\mathbf{H}_{2}$ & & Impromidine & $\mathbf{H}_{2}$ & 0 \\
\hline
\end{tabular}

Confluent monolayers of human endothelial cells from different donors in two separate experiments were stimulated for 5 min with $10^{-5} \mathrm{M}$ histamine in the presence or absence of receptor-selective antagonists, also at $10^{-5} \mathrm{M}$. Alternatively, cell monolayers were stimulated for 5 min with $10^{-5} \mathrm{M}$ receptor-selective agonists, except that impromidine was present at $10^{-6} \mathrm{M}$. PAF was quantitated as described in Methods and is presented as percent of the amount of PAF elicited by histamine.

by human endothelial cells is also a consequence of the stimulation of a bradykinin $B_{2}$ receptor.

ATP stimulates endothelial cell PAF and $\mathrm{PGI}_{2}$ synthesis. The induction of both PAF and $\mathrm{PGI}_{2}$. synthesis by three endothelial cell agonists suggested that this coupled synthesis might be of a general nature. Examination of a number of biologic compounds (13a) revealed that exogenous ATP was able to stimulate endothelial cells to synthesize PAF (Table III). This stimulation of PAF synthesis was time-dependent (Fig. 6), with the maximal accumulation occurring $\sim 15$ min

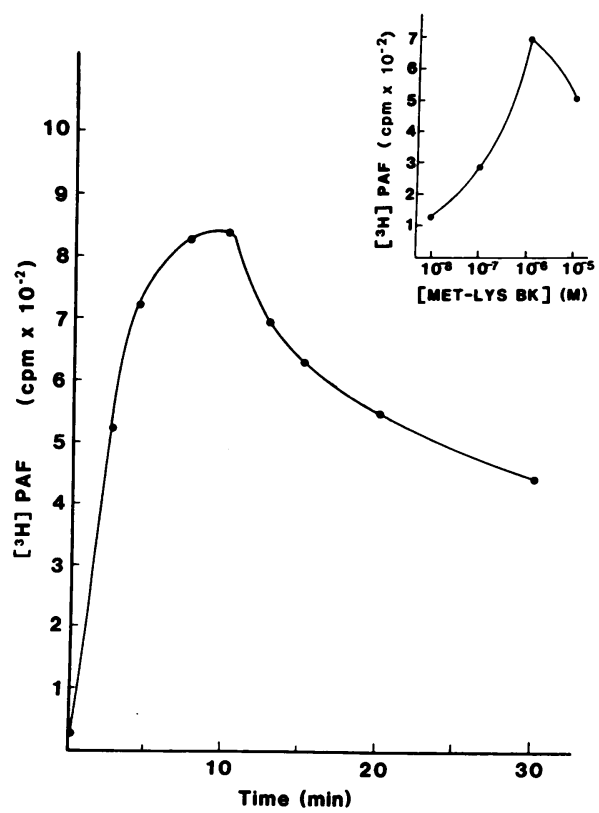

Figure 4. Met-Lys-bradykinin stimulation of PAF accumulation by human endothelial cells is time-dependent and concentration-dependent. Endothelial cells were stimulated with $10^{-6} \mathrm{M}$ Met-Lys-bradykinin in the presence of $\left[{ }^{3} \mathrm{H}\right]$ acetate for the designated periods of time and the amount of labeled PAF produced was quantitated as described in Methods. (Inset) The effect of varied concentrations of Met-Lys-bradykinin on the amount of PAF produced during a 10min stimulation. The data from this experiment are identical to those obtained in another experiment using cultures derived from a different donor. after ATP addition to the cells. The subsequent loss of the accumulated PAF proceeded linearly with the result that a little over $25 \%$ of the total PAF remained $30 \mathrm{~min}$ after ATP stimulation. The stimulation of PAF synthesis was detectable at $1 \mu \mathrm{M}$ ATP, but there was little increased stimulation with ATP concentration until $300 \mu \mathrm{M}$ ATP (not shown). This probably resulted from the rapid hydrolysis of extracellular

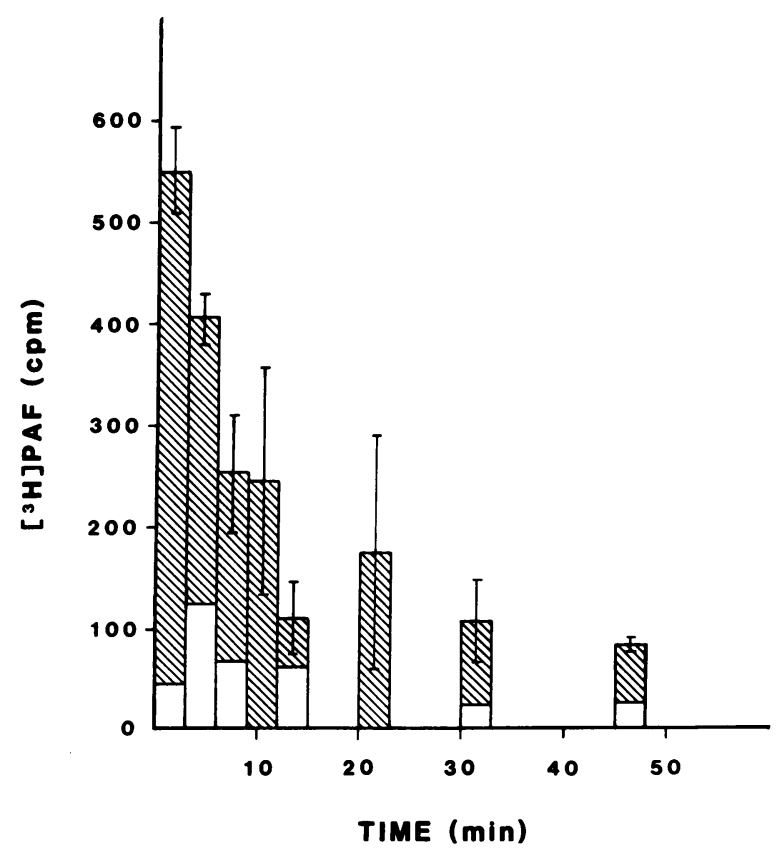

Figure 5. Synthesis of PAF by human endothelial cells as a function of time of Met-Lys-bradykinin stimulation. Confluent monolayers of endothelial cells were stimulated with $10^{-6} \mathrm{M}$ Met-Lys-bradykinin in buffer lacking $\left[{ }^{3} \mathrm{H}\right]$ acetate (time 0 ). At the designated time, the unlabeled medium was exchanged for $1 \mathrm{ml}$ of buffer containing $50 \mu \mathrm{Ci}$ of $\left[{ }^{3} \mathrm{H}\right]$ acetate in addition to $10^{-6} \mathrm{M}$ Met-Lys-bradykinin. The cells were incubated for $3 \mathrm{~min}$ before the assay was terminated with acidic methanol, and the amount of radiolabeled PAF synthesized during the 3-min period was quantitated as described in Methods. The amount of $\left[{ }^{3} \mathrm{H}\right] \mathrm{PAF}$ produced by this protocol in the absence of MetLys-bradykinin is shown by the open bars. These data are the result of two separate experiments using cells derived from different donors. 
Table II. Bradykinin Stimulates Endothelial Cell $P A F$ and $\mathrm{PGI}_{2}$ Synthesis via a $B_{2}$-type Receptor

\begin{tabular}{|c|c|c|}
\hline Addition & {$\left[{ }^{3} \mathrm{H}\right] \mathrm{PAF}$} & $\mathrm{PGI}_{2}$ \\
\hline & cpm/dish & ng of 6-keto-PGF $F_{1 a} /$ dish \\
\hline Bradykinin & 399 & 5.0 \\
\hline+ des-Arg $^{9}-\left[\mathrm{leu}^{8}\right]$ Bradykinin & 371 & 7.3 \\
\hline Lys-Bradykinin & 337 & 5.6 \\
\hline Met-Lys-Bradykinin & 293 & 6.8 \\
\hline+ des-Arg ${ }^{9}-\left[\right.$ leu $\left.^{8}\right]$ Bradykinin & 401 & 6.0 \\
\hline des-Arg ${ }^{9}$-Bradykinin & 108 & 2.3 \\
\hline None & 80 & 2.6 \\
\hline
\end{tabular}

Confluent monolayers of human endothelial cells were stimulated with the designated bradykinin homologues at $10^{-6} \mathrm{M}$ in the presence or absence of the $B_{1}$ receptor-specific antagonist des-Arg'[leu ${ }^{8}$ ]bradykinin, also present at $1 \mu \mathrm{M}$. The amount of PAF generated in $5 \mathrm{~min}$ or the amount of prostacyclin (measured as 6-keto$\mathrm{PGF}_{1 \alpha}$ ) released in $10 \mathrm{~min}$ was determined as described in Methods. These results showing the presence of bradykinin $B_{2}$-receptors on human endothelial cells are supported by the results of three other separate experiments.

ATP by cultured endothelial cells (22). However, the presence of the hydrolysis products ADP, AMP, or adenosine was not responsible for ATP bioactivity as these compounds were unable to induce PAF synthesis (Table III). In addition, inosine and its phosphorylated derivatives, possible metabolites of ATP, were not able to stimulate PAF production (not shown). Deoxy-ATP was $\sim 80 \%$ as effective as ATP, but the nonhydrolyzable ATP analogues containing an $\alpha, \beta$-methylene or $\beta, \gamma$ methylene bridge were not agonists for PAF production. The slowly hydrolyzable $\beta, \gamma$-imido ATP derivative demonstrated $\sim 15 \%$ of the activity of ATP.

Exogenous ATP also stimulated human umbilical vein endothelial cells to release $\mathrm{PGI}_{2}$ (Table III). This is consistent with the previous demonstration (7) that porcine aortic endothelial cells synthesize small amounts of $\mathrm{PGI}_{2}$ in response to extracellular ATP. The release of $\mathrm{PGI}_{2}$ by human cells was

Table III. ATP Stimulates PAF and $\mathrm{PGI}_{2}$ Synthesis by Endothelial Cells

\begin{tabular}{lll}
\hline Addition & {$\left[{ }^{3} \mathrm{H}\right] \mathrm{PAF}$} & $\mathrm{PGI}_{2}$ \\
\hline & cpm/dish & ng of 6-keto-PGF Ia $_{\text {dish }}$ \\
ATP & 594 & 4.8 \\
ADP & 120 & 3.2 \\
AMP & 104 & - \\
Adenosine & 63 & - \\
None & 80 & 2.5 \\
\hline
\end{tabular}

Endothelial cells were stimulated with $10^{-3} \mathrm{M}$ ATP or other adenoside derivatives at $10^{-3} \mathrm{M}$, and the amount of $\mathrm{PGI}_{2}$, as 6-keto-PGF $\mathrm{F}_{1 \alpha}$, present after $7 \mathrm{~min}$ or the amount of PAF present after $15 \mathrm{~min}$, was determined as described in Methods. The results are typical of three independent experiments.

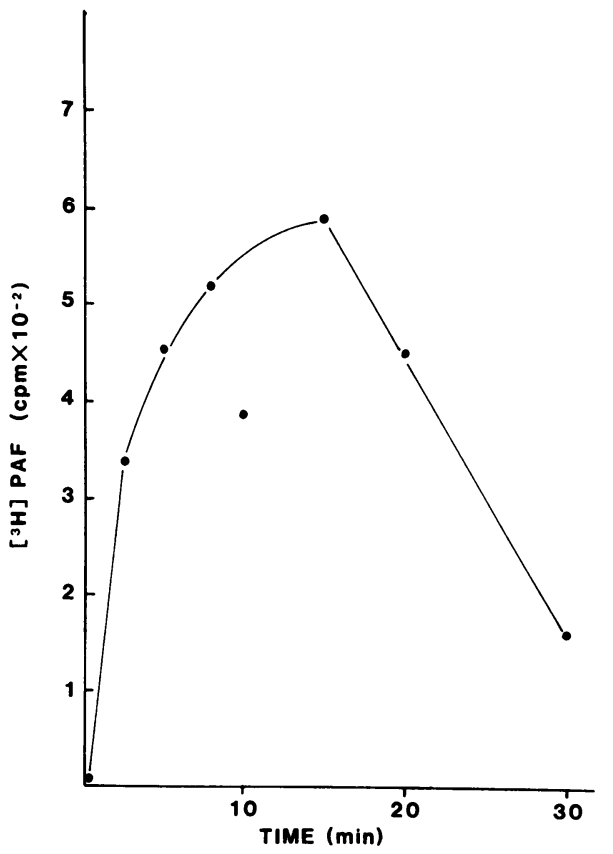

Figure 6. Adenosine triphosphate stimulation of PAF synthesis is time-dependent. Confluent monolayers of human endothelial cells were stimulated with $10^{-3} \mathrm{M}$ ATP in the presence of $\left[{ }^{3} \mathrm{H}\right]$ acetate, and the amount of PAF generated was determined as described in Methods. A second experiment with endothelial cells from a different donor gave similar results.

time-dependent (not shown) and amounted to about twice the amount induced by exchanging growth medium for assay buffer ("control"). Other phosphorylated adenosine derivatives, the $\beta, \gamma$-methylene-ATP analogue, or adenosine itself did not induce $\mathrm{PGI}_{2}$ synthesis. Thus, ATP induced the synthesis of both PAF and $\mathrm{PGI}_{2}$ by stimulation of what appeared to be a common, or very similar, mechanism.

$P A F$ remains cell-associated. We have previously observed that the PAF elicited upon thrombin stimulation of endothelial cells was not released into the medium, but instead remained associated with the cell monolayer (10). Fig. 7 shows that the PAF synthesized in response to histamine, Met-Lys-bradykinin or ATP was also localized to the endothelial cells. Separation of the assay medium from the cell monolayer showed that 99\% of the radiolabeled PAF synthesized in response to any agonist was associated with the cells, and that release of PAF was increased to no more than $2 \%$ of the total $\left[{ }^{3} \mathrm{H}\right] \mathrm{PAF}$ even when physiologic concentrations of albumin were included in the assay buffer. For comparison, the relative amount of PAF excreted from thrombin-stimulated cells in this experiment in the presence of $50 \mathrm{mg} / \mathrm{ml}$ bovine serum albumin (BSA) was $0.6 \%$. Such data show that endothelial cell-generated PAF is not likely to be secreted from the endothelium and this PAF cannot function as a hormone.

$P A F$ is not an endothelium-derived relaxing factor. The agonists thrombin, histamine, bradykinin, and ATP have been shown to induce endothelium to elaborate an unidentified vasodilator $(18,23)$, termed endothelial-derived relaxing factor, or EDRF, that mediates the vasodilation induced by these agonists. In that PAF is a potent hypotensive agent (24), and is made by endothelial cells in response to the same agonists that induce EDRF (23), it was of interest to determine if PAF 


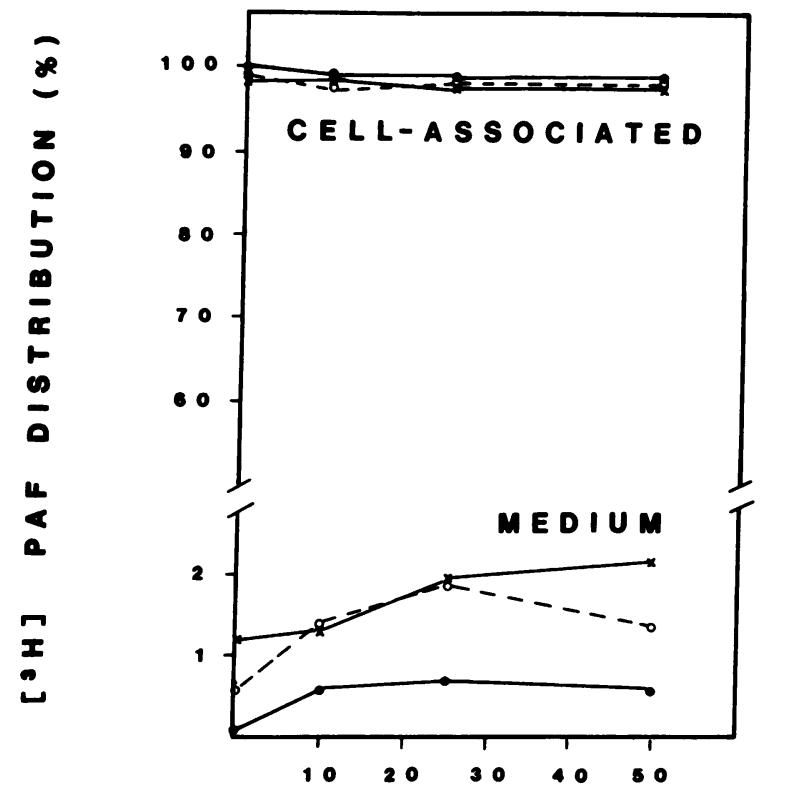

BSA CONCENTRATION (mg/mI)

Figure 7. PAF remains associated with endothelial cells. The localization of histamine-, bradykinin-, or ATP-elicited PAF was examined in the absence or in the presence of increasing concentrations of essentially fatty acid-free BSA in the assay medium. After a 10-min stimulation, the medium was removed, the cell monolayer and its supernatant were acidified with HOAc in methanol, and these fractions were separately processed as described in Methods. The data is presented as the percentage of total counts associated with the fraction. The total amount of $\left[{ }^{3} \mathrm{H}\right] \mathrm{PAF}$ generated in BSA-free assay medium was: thrombin, $11,430 \mathrm{cpm}$; histamine $(x), 3,515 \mathrm{cpm}$; MetLys-bradykinin (๑), $407 \mathrm{cpm}$; ATP (o), 1,844 cpm. The association of PAF with the cell monolayer, rather than release of the newly synthesized PAF into the bathing medium, has been observed in six separate experiments. is an EDRF. The assay for EDRF activity employed an ex vivo arterial ring preparation, derived from a canine femoral artery, equilibrated at a stable resting tension of $2 \mathrm{~g}$. Addition of norepinephrine to the ring (Fig. 8) resulted in a strong contraction, indicating that the arterial smooth muscle was viable. The addition of acetylcholine to the contracted ring caused a relaxation to $60 \%$ of the maximal tension. Reinitiation of the flow of perfusate removed these effectors and allowed the ring to return to its resting tension. The addition of PAF to this relaxed ring did not induce a contractile response, nor did it interfere with the subsequent norepinephrine-induced contraction. The ability of the ring to contract had not been altered by the previous manipulations inasmuch as the tension generated during the second contraction was identical to that of the initial response. The addition of PAF to the contracted arterial ring did not induce the relaxation of this tissue. The small increase in tension upon the addition of PAF also occurred when the washout of the preparation was initiated. From these results, we conclude that PAF does not directly affect arterial vascular tone and is not an EDRF.

\section{Discussion}

Human endothelial cells in culture are stimulated by thrombin, histamine, bradykinin, and extracellular ATP. These compounds are vasoactive agonists that mediate reactions in the coagulation pathway and in the acute inflammatory response. The endothelial cell response to these agonists previously has been characterized as the induction of $\mathrm{PGI}_{2}$ synthesis (3-7). We now show that these same agonists also simultaneously induce the synthesis of PAF. Further, where more than one type of receptor is known to exist, as for histamine and bradykinin, the induction of PAF and $\mathrm{PGI}_{2}$ synthesis occurred in response to activation of the same receptor subtype. That PAF is also synthesized in response to these $\mathrm{PGI}_{2}$ agonists is paradoxical in that PAF is an equally potent lipid autocoid that opposes the inhibitory actions of $\mathrm{PGI}_{2}$ on platelets and

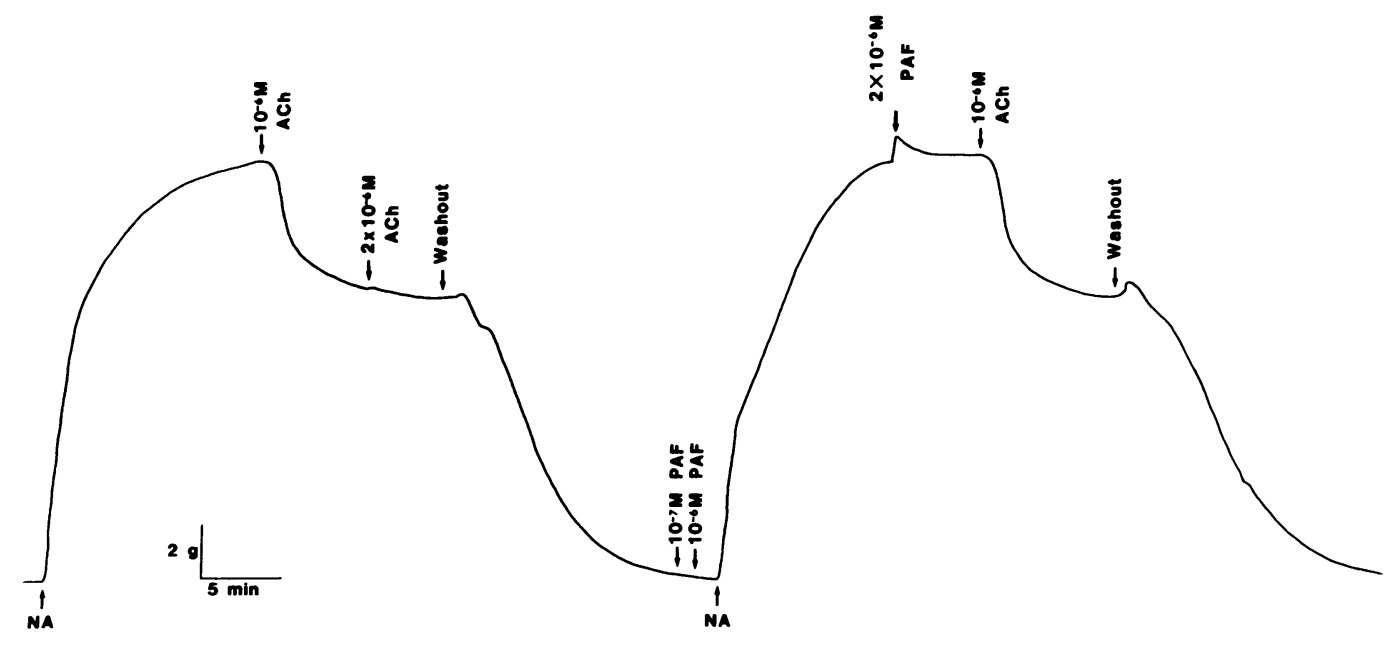

Figure 8. Effect of PAF on the tension of an ex vivo arterial preparation. A 5-mm canine femoral arterial ring was mounted between an immobilized hook in an organ bath and a hook attached to a strain gauge. The ring was perfused and a continuous record of tension was obtained as described in Methods. Similar results were obtained with arterial preparations from two other dogs, and when the agents were added in different sequences. Abbreviations are: $N A, 10^{-6} \mathrm{M}$ noradrenaline; $A C h$, acetylcholine; $P A F$, platelet-activating factor; WASHOUT, reinitiation of buffer flow. 
neutrophils. Although agonist stimulation results in the coinduction of PAF and $\mathrm{PGI}_{2}$ synthesis, we have shown here that temporal and spatial differences exist in the elaboration of PAF and $\mathrm{PGI}_{2}$ by endothelial cells: the production of PAF is a protracted process in contrast to the brief period of $\mathrm{PGI}_{2}$ synthesis; and endothelial cell-generated PAF remains associated with the cells rather than being released into the medium like $\mathrm{PGI}_{2}$.

The $\left[{ }^{3} \mathrm{H}\right]$ acetate-labeled lipid synthesized in response to histamine, bradykinin, exogenous ATP, and thrombin has been shown to be PAF (1-alkyl-2-acetyl-sn-glycero-3-phosphocholine) by (a) chromatography in two TLC systems, (b) elution with authentic PAF in the HPLC system of Blank and Snyder (17), (c) loss of acetate label and biologic activity by phospholipase $\mathrm{A}_{2}$ treatment or saponification, $(d)$ resistance to phospholipase $\mathrm{A}_{1},(e)$ incorporation of label from $1-\left[{ }^{3} \mathrm{H}\right]$ alkylsn-glycero-3-phosphocholine (10), and $(f)$ the ability to aggregate both platelets and neutrophils, an unusual property of PAF. The amount of PAF produced by endothelial cells is large enough to suggest that it is biologically significant as $10^{6}$ cells synthesized $0.1-0.2 \mathrm{nmol}$ within $10 \mathrm{~min}$ when stimulated with thrombin (10). If this PAF was released, this would be sufficient to produce up to 1 liter of bioactive fluid because the stimulation of platelet and neutrophil function $(10,25)$ can be detected at PAF concentrations as low as $10^{-10} \mathrm{M}$. The retention of PAF by endothelial cells may serve to further concentrate this mediator and potentiate its effect. The data in Table IV show that, although histamine, bradykinin, and ATP were less potent than thrombin, these agonists still cause a substantial, and presumably physiologically significant, accumulation of PAF. The amount of PAF and $\mathrm{PGI}_{2}$ synthesized by endothelial cells was variable, which was a reflection of the variation among primary cultures derived from different umbilical veins. Duplicate assays using cells from the same source were within $5 \%$ of the mean value. Such variability of primary cultures of human endothelial cells has also been observed for histamine stimulation of prostacyclin production (Baenziger, N. L., personal communication).

Accumulation of PAF as a result of agonist stimulation of endothelial cell receptors was an immediate response. This accumulation proceeded linearly during the initial $5 \mathrm{~min}$ of stimulation and reached its maximal value in 10-15 min. Although the subsequent decline proceeded at a variable rate, the rate was sufficiently slow so that the amount of PAF

Table IV. Agonist-induced PAF and PGI ${ }_{2}$ Production by Primary Endothelial Cell Cultures

\begin{tabular}{lcccc}
\hline Agonist & PAF & \multicolumn{3}{c}{$\mathrm{PGI}_{2}$} \\
\hline & cpm $/ 10^{6}$ cells & $(n)$ & $n g / 10^{6}$ cells & $(n)$ \\
Thrombin & $13,169 \pm 6,419$ & $(6)$ & $33.9 \pm 11.6$ & $(4)$ \\
Histamine & $4,194 \pm 2,211$ & $(6)$ & $16.8 \pm 13.2$ & $(4)$ \\
Bradykinin & $950 \pm 69$ & $(3)$ & $5 \pm 1.1$ & $(4)$ \\
ATP & $979 \pm 461$ & $(4)$ & $2.2 \pm 0.7$ & $(7)$ \\
\hline
\end{tabular}

Confluent monolayers of endothelial cells derived from various umbilical veins were stimulated with an agonist for $10 \mathrm{~min}$ and the amount of $\mathrm{PAF}$ or $\mathrm{PGI}_{2}$ generated was quantitated as described in Methods. The background in each experiment was subtracted before calculation of the mean of the stated number of experiments. remaining was significantly above background even 30-60 min after the addition of agonist. At least part of the persistence of endothelial cell PAF reflected the continued synthesis of PAF throughout this period. The apparent synthetic rate was greatest during the initial $3 \mathrm{~min}$, with a subsequent progressive decline in this rate. However, $30 \mathrm{~min}$ after stimulation, synthesis was still estimated to be $25 \%$ of the initial rate, and the synthesis of PAF was clearly detectable even $45 \mathrm{~min}$ after agonist stimulation. In contrast to the prolonged period of PAF synthesis, the period of active $\mathrm{PGI}_{2}$ synthesis was short-lived; the burst of $\mathrm{PGI}_{2}$ synthesis terminated in less than $7.5 \mathrm{~min}$ after its initiation. This ephemeral synthesis of $\mathrm{PGI}_{2}$ has been consistently observed under a variety of experimental protocols $(3,4,6,7)$ and appears to result from the self-inactivation of prostaglandin synthetase $(26,27)$.

Endothelial cells synthesized both $\mathrm{PAF}$ and $\mathrm{PGI}_{2}$ in response to exogenous ATP. The specificity demonstrated by endothelial cells for exogenous ATP, or deoxy-ATP, to induce the synthesis of PAF and $\mathrm{PGI}_{2}$ suggests that a single type of receptor may mediate the activation of both synthetic pathways. The human endothelial cell ATP receptor does not display the accepted specificity of a $P_{1}$-purinergic receptor (28), nor does the human umbilical endothelial cell display the $P_{2}$-purinergic receptor responsible for the ATP-, ADP-, or $\beta, \gamma$-imido-ATP-dependent release of $\mathrm{PGI}_{2}$ from cultured porcine or bovine aortic endothelial cells $(7,29)$. The synthesis of both PAF and $\mathrm{PGI}_{2}$ by human endothelial cells most closely resembles the ATP- or deoxy-ATP-specific release of histamine from rat mast cells (30). Stimulation of ATP receptors by ATP may occur in response to two sources of extracellular ATP: secretion of the contents of platelet-dense granules releases nearly as much ATP as ADP; and thrombin stimulation of human endothelial cells causes the selective release of a majority of the ATP pool of the cell (22). The presence of extracellular ATP in vivo is also suggested by an endothelial cell ecto-ATP hydrolase activity (22). The rapid hydrolysis of extracellular ATP by this activity may serve to limit the stimulation of $\mathrm{PAF}$ and $\mathrm{PGI}_{2}$ by secreted ATP.

We have employed agonists and antagonists specific for histamine or bradykinin receptor subtypes to show that the induction of both PAF and $\mathrm{PGI}_{2}$ synthesis proceeds from the stimulation of a single receptor subtype. Specifically, this was a histamine $\mathrm{H}_{1}$ or a bradykinin $\mathrm{B}_{2}$ receptor. The inflammatory response induced by agents such as bradykinin and histamine may depend upon this concerted synthesis of PAF and $\mathbf{P G I}_{2}$. The actions of histamine previously have been characterized as the direct inhibition of polymorphonuclear neutrophil (PMN) function (31), as well as the synthesis by endothelium of the polymorphonuclear leukocyte inhibitor, $\mathrm{PGI}_{2}$ (4). PAF is the first activator of inflammatory cell types found to be synthesized in response to histamine and bradykinin. Thus, this endothelial cell-associated PAF may recruit inflammatory cell types to the site of inflammation and then activate them. $\mathbf{P G I}_{2}$, which temporarily may antagonize the effect of PAF on blood-borne cells, may aid this PAF-mediated cellular recruitment through capillary bed vasodilation and increased blood flow. There is as yet no evidence that PAF can directly participate in this vasodilation. Although PAF will cause profound hypotension upon injection into a test animal $(24,32)$, and the same agonists that induce endothelial cell PAF synthesis also induce the synthesis of EDRF (23), PAF was shown to have no effect on the vascular smooth muscle tension of a major vessel. The 
stimulation of PAF and $\mathrm{PGI}_{2}$ synthesis by histamine and bradykinin shows that endothelial cells are an active participant in the process of acute inflammation, a role of endothelium originally postulated by Metchnikoff (33).

Endothelium normally presents a nonthrombotic surface to the lumen of the vessel, yet under some circumstances it does become thrombogenic. The demonstration that human endothelial cells synthesize and retain PAF in response to physiologic agonists may be a mechanism by which this alteration is effected. The association of PAF with endothelial cells was not altered by the presence of physiologic concentrations of albumin, which is capable of sequestering PAF (34). Although this PAF was not readily extractable, phospholipase digestion indicates that at least a portion of this PAF is present at the cell surface (Prescott, S. M., G. A. Zimmerman, and T. M. McIntyre, unpublished observations). Alteration of the surface of the endothelium and the enhanced binding and activation of neutrophils and platelets would have several sequelae: thrombus formation; damage of the endothelium by degradative enzymes and activated oxygen species; access of blood-borne elements, including lipoproteins, to the subendothelial space; and the release of platelet-derived growth factor, a potent smooth muscle and fibroblast mitogen. Several of these potential consequences have been hypothesized to be pathogenic events in the formation of an atherosclerotic plaque (35) and in other forms of vascular injury (36). The coinduction of $\mathrm{PGI}_{2}$ synthesis might temporarily counteract these events, due to its short-lived synthesis, but also may potentiate these cell-mediated sequelae through vasodilation-induced cell recruitment. The production of PAF by endothelium may also function as a homeostatic process. Platelets have been shown to possess an endothelial cell growth factor (37), and it is known that in some manner platelets are required for the maintenance of vascular integrity $(38,39)$. In addition, PAF has recently been shown to induce angiogenesis in the chick chorio-allantoic membrane (40). It is apparent that through the induction of PAF synthesis and accumulation by endothelial cells, and the co-induction of $\mathrm{PGI}_{2}$ synthesis, that the endothelium can be an active participant in inflammatory, homeostatic, and pathologic processes.

\section{Acknowledgments}

The authors are indebted to Dr. K. Spitzer for his significant participation in the recording of vascular tension, to the Nora Eccles Harrison Cardiovascular Research and Training Institute electronic core facility personnel for their aid, and to Dr. S. Harvey for the use of a strain gauge. The technical assistance of Donelle Benson in the culturing of endothelial cells, and the collection of umbilical cords by the LDS Hospital Delivery Room staff is gratefully acknowledged. We thank Leona Archuleta and Doris Land for typing this manuscript, and Scott Shafer and Carol Evans for the preparation of the figures.

This work was supported in part by grants from the Nora Eccles Treadwell Foundation, the Utah Heart Association, and the Montana Heart Association. Dr. Zimmerman is a recipient of U. S. Public Health Service Clinical Investigator Award HL-00696 from the National Heart, Blood and Lung Institute.

\section{References}

1. Moncada, S., A. G. Herman, E. A. Higgs, and J. R. Vane. 1977. Differential formation of prostacyclin (PGX or $\mathrm{PGI}_{2}$ ) by layers of the arterial wall. An explanation for the anti-thrombotic properties of vascular endothelium. Thromb. Res. 11:323-344.
2. Weksler, B. B., A. J. Marcus, and E. A. Jaffe. 1977. Synthesis of prostaglandin $I_{2}$ (prostacyclin) by cultured human and bovine endothelial cells. Proc. Natl. Acad. Sci. USA. 74:3922-3926.

3. Weksler, B. B., C. W. Ley, and E. A. Jaffe. 1978. Stimulation of endothelial cell prostacyclin production by thrombin, trypsin, and the ionophore A23187. J. Clin. Invest. 62:923-930.

4. Baenziger, N. L., L. E. Force, and P. R. Becherer. 1980. Histamine stimulates prostacyclin synthesis in cultured human umbilical vein endothelial cells. Biochem. Biophys. Res. Commun. 92:14351440.

5. Hong, S. L. 1980. Effect of bradykinin and thrombin on prostacyclin synthesis in endothelial cells from calf and pig aorta and human umbilical cord vein. Thromb. Res. 18:787-795.

6. Cramer, E. B., L. Pologe, N. A. Pawlowski, Z. A. Cohn, and W. A. Scott. 1983. Leukotriene C promotes prostacyclin synthesis by human endothelial cells. Proc. Natl. Acad. Sci. USA. 80:4109-4113.

7. Pearson, J. D., L. L. Slakey, and J. L. Gordon. 1983. Stimulation of prostaglandin production through purinoceptors on cultured porcine endothelial cells. Biochem. J. 214:273-276.

8. Czervionke, R. L., J. C. Hoak, and G. L. Fry. 1978. Effect of aspirin on thrombin-induced adherence of platelets to cultured cells from the blood vessel wall. J. Clin. Invest. 62:847-856.

9. Barnhart, M. I., and S. T. Chen. 1978. Vessel wall models for studying interaction capabilities with blood platelets. Semin. Thromb. Hemostasis. 5:112-155.

10. Prescott, S. M., G. A. Zimmerman, and T. M. McIntyre. 1984. Human endothelial cells in culture produce platelet-activating factor (1-alkyl-2-acetyl-sn-glycero-3-phosphocholine) when stimulated with thrombin. Proc. Natl. Acad. Sci. USA. 81:3534-3538.

11. Camussi, G., M. Aglietta, F. Malavasi, C. Tetta, W. Piacibello, F. Sanavio, and F. Bussolino. 1983. The release of platelet-activating factor from human endothelial cells in culture. J. Immunol. 131:23972403.

12. Demopoulos, C. A., R. N. Pinckard, and D. J. Hanahan. 1979. Platelet-activating factor: evidence for 1-O-alkyl-2-acetyl-sn-glyceryl-3phosphorylcholine as the active component (a new class of lipid chemical mediators). J. Biol. Chem. 254:9355-9358.

13. O'Flaherty, J. T., R. L. Wykle, C. H. Miller, J. C. Lewis, M. Waite, D. A. Bass, C. E. McCall, and L. R. DeChatelet. 1981. 1-Oalkyl-sn-glyceryl-3-phosphorylcholines: a novel class of neutrophil stimulants. Am. J. Pathol. 103:70-78.

13a. Zimmerman, G. A., T. M. McIntyre, and S. M. Prescott. 1985. Human vascular endothelial cells produce platelet-activating factor (1-alkyl-2-acetyl-sn-glycero-3-phosphocholine): evidence for a requirement for specific agonists and modulation by prostacyclin. Circulation. In press.

14. Bligh, E. G., and W. J. Dyer. 1959. A rapid method of total lipid extraction and purification. Can. J. Biochem. Physiol. 37:911917.

15. Mueller, H. W., J. T. O'Flaherty, and R. L. Wykle. 1983. Biosynthesis of platelet-activating factor in rabbit polymorphonuclear neutrophils. J. Biol. Chem. 258:6213-6218.

16. Caramello, C., S. Fernanez-Gallardo, D. Marin-Cao, P. Inarrea, J. C. Santos, J. M. Lopez-Novoa, and M. Sanchez Crespo. 1984. Presence of platelet-activating factor in blood from humans and experimental animals. Its absence in anephric individuals. Biochem. Biophys. Res. Commun. 120:789-796.

17. Blank, M. L., and F. Synder. 1983. Improved high-performance liquid chromatographic method for isolation of platelet-activating factor from other phospholipids. J. Chromatogr. 273:415-420.

18. Furchgott, R. F., and J. V. Zawadski. 1980. The obligatory role of endothelial cells in the relaxation of arterial smooth muscle by acetylcholine. Nature (Lond.). 288:373-376.

19. Douglas, W. W. 1980. Histamine and 5-hydroxytryptamine (seratonin) and their antagonists. In The Pharmacological Basis of Therapeutics. A. G. Gilman, L. S. Goodman, and A. Gilman, editors, Macmillan Publishing Co., New York. 609-646.

20. Durant, G. J., W. A. M. Duncan, C. R. Ganellin, M. E. 
Parsons, R. C. Blakemore, and A. C. Rasmussen. 1978. Impromidine (SK \& F 92676) is a very potent and specific agonist for histamine $\mathrm{H}_{2}$ receptors. Nature (Lond.). 276:403-405.

21. Regoli, D., and J. Barabe. 1980. Pharmacology of bradykinin and related kinins. Pharmacol. Rev. 32:1-46.

22. Pearson, J. D., and J. L. Gordon. 1979. Vascular endothelial and smooth muscle cells in culture selectively release adenine nucleotides. Nature (Lond.). 281:384-386.

23. Furchgott, R. F. 1983. Role of endothelium in responses of vascular smooth muscle. Circ. Res. 53:557-573.

24. Blank, M. L., F. Snyder, L. W. Byers, B. Brooks, and E. E. Muirhead. 1979. Antihypertensive activity of an alkyl ether analog of phosphatidylcholine. Biochem. Biophys. Res. Commun. 90:1194-1200.

25. Shaw, J. O., R. N. Pinckard, K. S. Ferrigni, L. M. McManus, and D. J. Hanahan. 1981. Activation of human neutrophils with 1-Ohexadecyl/octadecyl-2-acetyl-sn-glyceryl-3-phosphorylcholine (plateletactivating factor). J. Immunol. 127:1250-1255.

26. Brotherton, A. F. A., and J. C. Hoak. 1983. Prostacyclin biosynthesis in cultured vascular endothelium is limited by deactivation of cyclooxygenase. J. Clin. Invest. 72:1255-1261.

27. Egan, R. W., J. Paxton, and F. A. Kuehl, Jr. 1976. Mechanism for irreversible self-deactivation of prostaglandin synthetase. J. Biol. Chem. 251:7329-7335.

28. Burnstock, G. 1981. Neurotransmitters and trophic factors in the autonomic nervous system. J. Physiol. (Lond.). 313:1-35.

29. van Coevorden, A., and J. M. Boeynaems. 1984. Physiological concentrations of ADP stimulate the release of prostacyclin from bovine aortic endothelial cells. Prostaglandins. 27:615-626.

30. Lagunoff, D., and E. Y. Chi. 1980. Cell biology of mast cells and basophils. In Cell Biology of Inflammation. G. Weissmann, editor, Elsevier/North-Holland Publishing Co., Amsterdam. 217-265.

31. Bussee, W. W. 1979. Histamine: mediator and modulator of inflammation. In Handbook of Inflammation. L. E. Glynn, J. C. Hoak and G. Weissmann, editors. Chemical Messengers of the Inflammatory Process. Vol. I. J. C. Hoak, editor. Elsevier/North-Holland Publishing Co., Amsterdam. 1-45.

32. Kenzora, J. L., J. E. Perez, S. R. Bergmann, and L. G. Lange. 1984. Effects of acetyl glyceryl ether of phosphorylcholine (platelet activating factor) on ventricular preload, afterload, and contractility in dogs. J. Clin. Invest. 74:1193-1203.

33. Metchnikoff, E. 1905. Immunity in infectious diseases. Translated by F. G. Binnie. University Press, Cambridge, quoted by G. I. Gallen. 1980. The cell biology of leukocyte chemotaxis. In The Cell Biology of Inflammation. G. Weissmann, editor, Elsevier/North-Holland Publishing Co., Amsterdam. 299-335.

34. Cabot, M. C., M. L. Blank, C. J. Welsh, M. J. Horan, E. A. Cress, and F. Snyder. 1982. Metabolism of 1-alkyl-2-acetyl-sn-glycero3-phosphocholine by cell cultures. Life Sci. 31:2891-2898.

35. Ross, R., and J. A. Glomset. 1976. The pathogenesis of atherosclerosis. $N$. Engl. J. Med. 295:420-425.

36. Jacob, H. S., P. R. Craddock, D. E. Hammerschmidt, and C. F. Moldow. 1980. Complement-induced granulocyte aggregation: An unsuspected mechanism of disease. N. Engl. J. Med. 302:789-794.

37. King, G. L., and S. Buchwald. 1984. Characterization and partial purification of an endothelial cell growth factor from human platelets. J. Clin. Invest. 73:392-396.

38. Gimbrone, M. A., R. H. Aster, R. S. Cotran, J. Corkery, J. H. Jandl, and J. Folkman. 1969. Preservation of vascular integrity in organs perfused in vitro with a platelet-rich medium. Nature (Lond.). 222:33-36.

39. Kitchens, C. S., and L. Weiss. 1975. Ultrastructural changes of endothelium associated with thrombocytopenia. Blood. 46:567-578.

40. Dusseau, J. W., M. C. Klein, and P. M. Hutchins. 1984. Platelet-activating factor induced angiogenesis on the chick chorioallantoic membrane. Fed. Proc. 43:588a. (Abstr.) 